\title{
Characterization of Glucomannan Extracted from Fresh Porang Tubers Using Ethanol Technical Grade
}

\author{
Nurlela ${ }^{1 *}$, Nina Ariesta ${ }^{1}$, Dwi Sutari Laksono', Edi Santosa² ${ }^{2}$ Tjahya Muhandri ${ }^{3}$ \\ 'Chemistry, Universitas Nusa Bangsa, Bogor, 16166, Indonesia \\ ${ }^{2}$ Agronomy and Horticulture, Bogor Agricultural University, Bogor, 16680, Indonesia \\ ${ }^{3}$ Food Science Technology, Bogor Agricultural University, Bogor, 16680, Indonesia \\ *Corresponding author email: nnurlela16@gmail.com
}

Received January 10, 2020; Accepted January 21, 2021; Available online March 25, 2021

\begin{abstract}
Glucomannan is a polysaccharide consisting of $\beta$-1.4-linked D-mannose and D-glucose monomers, which have many benefits especially in the food and pharmaceutical industry. It has been widely reported that one of the main sources of glucomannan is porang tuber (Amorphophallus muelleri Blume). Generally, glucomannan extracted or purified from porang flour. However, the drying process causes other compounds than glucomannan stick strongly, resulting low levels of glucomannan. This study was to obtain glucomannan extract in an easy, effective, and inexpensive method, by direct extraction from fresh porang tubers using ethanol technical grade. We performed two extraction methods. The first is a fixed concentration method, the sample was repeatedly extracted using 50\% ethanol (FC50) and 96\% ethanol (FC96) 3 times, respectively. The second is a multilevel concentration method, the sample was repeatedly extracted using ethanol $60 \%$ (first step), $80 \%$ (second step), and $96 \%$ (third step), one replication each step. The highest glucomannan content (66.56\%) was obtained by a multilevel concentration method. Moisture, lipid, protein, crude fiber, calcium oxalate level significantly reduce to $13.58 \%, 0.07 \%, 4.03 \%, 4.95 \%, 0.56 \%$ respectively. FTIR spectra confirmed the presence of functional groups $(\mathrm{O}-\mathrm{H}, \mathrm{C}=\mathrm{O}$, $\mathrm{C}-\mathrm{O}, \mathrm{C}-\mathrm{H})$, that compose the glucomannan compound. SEM image showed that the granules form of glucomannan were round and oval, began to change its phase from amorphous to crystalline, related to XRD data. The results showed that the direct extraction from fresh porang tuber using ethanol technical grade with a multilevel concentration method was an effective method to extract the glucomannan.
\end{abstract}

Keywords: Porang, Amorphophallus muelleri Blume, glucomannan, ethanol technical grade, multilevel concentration

\section{INTRODUCTION}

Glucomannan is a polysaccharide of the mannan family, very abundant in nature, specifically in softwoods, roots, tubers, and many plant bulbs (Nguyen, Do, Nguyen, Pham, \& Nguyen, 2011). In Indonesia, the main sources of glucomannan are porang or iles-iles. One of the types of iles-iles which has high glucomannan content is yellow porang (Amorphophallus oncophyllus Prain or Amorphophallus muelleri Blume), about 55 \% (dry basis) (Koswara, 2013). The benefits of glucomannan have been widely studied. In the food industry, glucomannan was used as a thickener of the syrup, jelly, edible film, noodle, and binder of sausage (Singh, Singh, \& Arya, 2018). In the pharmaceutical industry, glucomannan was used in the preparation of hydrogel as a DNA-controlled release matriks (Tester \& Al-Ghazzewi, 2017; Wang, Liu, Shuai, Cui, \& Nie, 2014; Wang et al., 2014; Y. Yuan et al., 2018). As a functional food, glucomannan functions to reduce cardiovascular risk factors (Ho et al., 2017), reduce body weight and treatment of diabetes ( $\mathrm{Li}$ et al., 2015).
The extraction process is one of the most important steps to produce glucomannan with high purity. Methods for the extraction and purification of glucomannan has been studied and developed. Glucomannan is extracted mechanically and chemically. The mechanical methods involve grinding and purified via wind-sifting (Parry, 2010; Takigami, 2000), grinding and purified via filtering, and polishing. The chemical methods have been carried out including centrifugation after flocculation using $\mathrm{Al}_{2}\left(\mathrm{SO}_{4}\right)_{3}$ (Tatirat \& Charoenrein, 2011), the use of dimethyl sulfoxide ( $Y e$ et al., 2014), and ethanol (Chua et al., 2012; W. Xu et al., 2014) to extract glucomannan.

Generally, glucomannan extracted or purified from porang flour. Porang tubers were peeled, sliced, dried, and then made into flour. Problems encountered in the development of porang flour as food in Indonesia are the high content of calcium oxalate, which causes itching, brownish color, and relatively low glucomannan content around $47-48 \%$ (Sumarwoto, 2014). Those characteristics of porang flour cause a low selling price. To increase the economic value, 
porang flour was extracted to obtain higher glucomannan content. But, the process of drying into flour, can make other components than glucomannan (impurities) stick strongly and reduce the purity of glucomannan. Therefore, we carry out the direct extraction of fresh porang tubers.

Granules of konjac glucomannan are located in egg-shaped idioblasts within the parenchyma. Starch, cellulose, and nitrogen-containing materials are present in the parenchyma cells surrounding the idioblasts within the corm (Chua, Hocking, Chan, \& Baldwin, 2013; Mekkerdchoo, Lei, \& Jianrong, 2020). Other components (the impurities) are small and easily broken into fine particles than glucomannan, which is bigger and harder (Yanuriati, Marseno, Rochmadi, \& Harmayani, 2017). Glucomannan is insoluble in ethanol ( Li et al., 2014) but soluble in water. Previous research showed that glucomannan extraction directly from fresh tubers using ethanol absolute with multilevel concentration method succeeded in obtaining high purity glucomannan. However, for scale-up and mass production purposes, the use of ethanol absolute is highly cost. This study was to obtain glucomannan extract in an easy, effective, and inexpensive method, by direct extraction from fresh porang tubers using ethanol technical grade. The impurities such as starch, protein, lipid, crude fiber, calcium oxalate have different levels of polarity. So we assume that by varying the concentration of ethanol solution in the extraction process (multilevel concentration method), it can dissolve impurities more effectively, so the high purity glucomannan can be obtained, without further purification

\section{EXPERIMENTAL SECTION \\ Extraction of Porang Glucomannan}

The three years old Porang/lles-iles Kuning (A. morphophallus muelleri Blume) tubers were obtained from the Bogor Agricultural University experimental garden, Bogor, Indonesia. Glucomannan was extracted from fresh porang tubers using ethanol technical grade. Porang tubers were peeled, washed, sliced to about $0,2-0,5 \mathrm{~mm}$ in thickness. Then it was soaked using $\mathrm{Na}$-metabisulphite for 30 minutes. In the first method, the extraction was repeated using ethanol with a fixed concentration, that sliced porang milled in $50 \%$ technical grade ethanol (FC50) and $96 \%$ ethanol technical grade (FC96), filtered and pressed. The process was repeated three times from the start of the milling, filtering, and pressing process for each FC50 and FC96. The obtained glucomannan granules were dried in the oven at $50^{\circ} \mathrm{C}$.

In the second method, the extraction was repeated using ethanol with multilevel concentration (MC). After soaking with $\mathrm{Na}$-metabisulphite, the sliced porang milled in $60 \%$ ethanol technical grade, filtered and pressed. Then the glucomannan granules are milled in $80 \%$ ethanol, filtered and pressed. The treatment repeated in $96 \%$ ethanol. The obtained glucomannan granules were dried in the oven at $50{ }^{\circ} \mathrm{C}$. The ratio of tubers (gram) and ethanol (ml) applied in both methods (fixed concentration and multilevel concentration) was 1:3.

The glucomannan yield ( $\mathrm{db}$ ) was calculated by the following formula:

$$
\text { Yield }=\frac{m_{1}\left(1-w_{1}\right) \times 100 \%}{m_{2}\left(1-w_{2}\right)}
$$

Where $\mathrm{m}_{1}=$ mass of dried glucomannan, $\mathrm{m}_{2}=$ mass of wet peeled porang tuber, $w_{1}=$ water content of dried glucomannan, and $w_{2}=$ water content of wet peeled porang tuber.

\section{Chemical Properties}

The tuber and glucomannan extract were determined for moisture, ash, fat, and protein, according to AOAC methods 967.03; 942.05; 920.39; 981.10 (Association of Official Analytical Chemists, 2007). The crude fiber content was measured by subtracting the sum of all the other components from $100 \mathrm{~g}$. The starch was analyzed qualitatively by staining glucomannan granules using $\mathrm{I}_{2}$-KI (Mekkerdchoo et al., 2020).

\section{Glucomannan Content}

Glucomannan content was analyzed using 3.5Dinitro Salicylic Acid (3.5-DNS) colorimetric assay (Chua et al., 2012). The glucomannan sample solution was made by dissolving $0.2 \mathrm{~g}$ extracted glucomannan in buffer solution (formic acid-sodium hydroxide $0.1 \mathrm{~mol} / \mathrm{L} 50 \mathrm{ml}$ ), then magnetically stirred for 4 hours at room temperature. The mixture was then diluted with formic acid-sodium hydroxide buffer to $100 \mathrm{~mL}$ in a volumetric flask, followed by centrifugation at $4000 \mathrm{rpm}$ for 20 minutes, the supernatant was glucomannan sample solution. The next step was to made glucomannan hydrolysate, 5 $\mathrm{mL}$ of glucomannan sample solution was added to 25 $\mathrm{mL}$ volumetric flask followed by the addition of $2.5 \mathrm{~mL}$ of $3 \mathrm{M}$ sulfuric acid, heated in boiling water bath for 90 minutes. The solution allowed to cool to room temperature then added $2.5 \mathrm{~mL}$ of $6 \mathrm{M} \mathrm{NaOH}$, then diluted with distilled water to $25 \mathrm{~mL}$. Both the glucomannan sample solution and hydrolysate $(2 \mathrm{~mL})$ were added 3.5 DNS reagent $(1.5 \mathrm{~mL})$. Absorbance was then measured at $550 \mathrm{~nm}$ used a UV-VIS spectrophotometer. The 3.5-DNS reagent was made by mixing solution $A(0.7 \mathrm{~g}$ phenol; $1.5 \mathrm{~mL}$ of $10 \%$ sodium hydroxide; $5 \mathrm{~mL}$ distilled water; and $0.7 \mathrm{~g}$ sodium bisulfite) with solution B (22.5 g potassium sodium tartrate; $30 \mathrm{~mL}$ of $10 \%$ sodium hydroxide; 88 $\mathrm{mL}$ dinitro salicylic acid 1\%).

$\mathrm{D}$-glucose and $\mathrm{D}$-mannose standard curves were built up by $\mathrm{d}$-Glucose stock solution $(1 \mathrm{mg} / \mathrm{mL})$ were placed $(0.40 ; 0.80 ; 1.20 ; 1.60$ and $2.00 \mathrm{~mL}$ ) into 25 $\mathrm{ml}$ volumetric flasks, respectively (using DI water as a blank). DI water was then added to the volume of 2.00 $\mathrm{mL}$, followed by the addition of 3.5-DNS $(1.50 \mathrm{~mL})$ to each flask. Each mixture was heated for $5 \mathrm{~min}$ in a boiling water bath and cooled to room temperature 
before being diluted to $25 \mathrm{~mL}$ with $\mathrm{DI}$ water in a volumetric flask. Absorbance was then measured at $550 \mathrm{~nm}$, and a plot of the measured absorbance against the glucose content $(\mathrm{mg})$ constructed. A dmannose standard curve was constructed using the procedure as described for glucose. The glucomannan content was calculated by the following equation:

$$
\text { GMcontent }(\%)=\frac{5000 f(5 T-T o)}{m(1-w)}
$$

Where $f=$ correction factor, $T=$ glucose content of glucomannan hydrolysate $(\mathrm{mg})$, To = glucose content of glucomannan sample solution (mg), $\mathrm{m}=$ mass of extracted glucomannan $(200 \mathrm{mg})$ and $\mathrm{w}=$ water content of glucomannan

\section{Statistical Analysis}

Statistical significance of the effect of the extraction methods based on the obtained of glucomannan and the chemical properties of extracted glucomannan was assessed with a one-way analysis of variance (ANOVA).

\section{Calcium Oxalate Content}

Calcium oxalate was analyzed by spectrophotometry (Ardhian, Dhike \& Indriyani, 2013). The sample weighed $5 \mathrm{~g}$. Then the furnace was treated with a temperature of $600-800{ }^{\circ} \mathrm{C}$ for 30 minutes and cooled for 3 hours. The residue added 10 $\mathrm{mL}$ of $\mathrm{HNO}_{3}$ :aquadest $(1: 1)$ solution. Then heated to $5 \mathrm{~mL}$. The mixture is filtered to a $25 \mathrm{~mL}$ volumetric flask so that the filtrate is obtained and then treated with an aquadest. Samples were analyzed using AAS. The calcium content of the AAS results is converted to the oxalate content with the following formula (Association of Official Analytical Chemists, 2007):

$$
\begin{aligned}
& \text { Oxalate level }=\frac{\text { Ca conc. }\left(\mu \frac{g}{m L}\right) \times \text { MW Ca oxalate } x \boldsymbol{S V}(\boldsymbol{m L})}{\text { sample weight }(\boldsymbol{g}) \boldsymbol{x} \boldsymbol{M W} \boldsymbol{C a}} \\
& \text { Where: } M W \text { Ca-oxalate }=128 \\
& M W \mathrm{Ca}=40 \\
& \text { Solvent volume }=25 \mathrm{~mL}
\end{aligned}
$$

\section{Characterization of Glucomannan}

The obtained glucomannan (FC50, FC96, MC, and commercial glucomannan) was determined its functional groups of glucose and mannose using Fourier Transform-Infra Red (FTIR) Thermo scientific iD5 ATR. XRD pattern of glucomannan was analyzed using XRD Maxima 7000 Shimadzu. The diffraction angle ranged from $2 \theta=10^{\circ}-2 \theta=80^{\circ}$. The XRD analysis was conducted to determine the phase of glucomannan granule and crystallinity of extracted glucomannan, then compared with the commercial glucomannan.

The SEM photomicrographs were recorded by using SEM-EDX Carl Zeiss Bruker type EVO MA1OTo study the morphology or the surface characteristic of extracted glucomannan.

\section{RESULTS AND DISCUSSION \\ Chemical Properties of Raw Material}

In this study, glucomannan extracted from fresh tubers of porang/iles-iles kuning (Amorphophallus muelleri Blume). The chemical composition of the porang tubers was presented in Table 1. The highest content in porang tubers was moisture content. High moisture content in raw food can cause some damage, including microbial growth, browning reactions, and fat hydrolysis. Therefore the process of handling post-harvest of porang tubers must be done quickly and correctly. Generally, porang farmers immediately process the harvested tubers into dried chips and sell them directly to collectors, but some people process them further into porang flour. This process conducted to reduce the moisture content of the material to inhibit the growth of microorganisms and the activity of enzymes.

One of the chemical methods to isolate glucomannan is extraction or repeated leaching using ethanol. Ethanol solution will dissolve the components (impurities) such as ash, starch, fat, protein, and crude fiber to obtain high level of glucomannan extract.

\section{Extraction of Porang Glucomannan}

In this study, the result showed the glucomannan granules extracted using ethanol with multilevel concentrations (MC) had the glucomannan content: $66.56 \%$, and yield: $51.35 \%$ (Table 2). It was higher than the glucomannan obtained by a fixed concentration method with $50 \%$ ethanol (FC50) and $96 \%$ ethanol (FC96). The impurities such as starch, lipids, protein, crude fiber have different polarity levels. Therefore it was more effective if extracted using ethanol with different concentrations. A one-way ANOVA was conducted to examine the effect of the extraction methods based on the obtained of glucomannan (Table 2). There were statistically significant deferences between the extraction methods using ethanol with fixed concentration FC50 and multilevel concentration (MC), but there were insignificant differences between the extraction methods FC50 and FC96; FC96 and MC.

\begin{tabular}{lc}
\multicolumn{2}{l}{ Table 1. Chemical Composition of Porang Tuber } \\
\hline Chemical Composition & Analysis Results (\%) \\
\hline Moisture & 84.01 \\
Ash & 0.83 \\
Starch & + \\
Fat & 0.83 \\
Protein & 9.50 \\
Crude Fiber & 9.70 \\
\hline
\end{tabular}

$+=$ dark blue colour (positive/indicated high starch content) 
Table 2. Glucomannan Content

\begin{tabular}{cccc}
\hline & \multicolumn{2}{c}{ Fixed Concentration } & Multilevel Concentration \\
\cline { 2 - 4 } & FC50 (\%) & FC96 (\%) & MC (\%) \\
\hline Glucomannan & $54.20 \pm 0.62^{\mathrm{a}}$ & $60.20 \pm 4.86^{\mathrm{a}, \mathrm{b}}$ & $66.56 \pm 0.63^{\mathrm{b}}$ \\
Yield & $49.99^{\mathrm{a}}$ & $51.99^{\mathrm{c}}$ & $51.35^{\mathrm{b}}$ \\
\hline Different superscripts among mean values in each row indicated a significant difference $(\mathrm{p} \leq 0.05)$
\end{tabular}

Table 3. Chemical Composition of Glucomannan Extract

\begin{tabular}{lccc}
\hline Chemical Composition & \multicolumn{2}{c}{ Fixed Concentration } & Multilevel Concentration \\
\cline { 2 - 4 } & FC50 (\%) & FC96 (\%) & MC (\%) \\
\hline Moisture & $14.07^{\mathrm{c}}$ & $13.13^{\mathrm{a}}$ & $13.58^{\mathrm{b}}$ \\
Ash & $1.46^{\mathrm{a}}$ & $1.71^{\mathrm{b}}$ & $1.66^{\mathrm{b}}$ \\
Starch & - & - & - \\
Lipid & $0.13^{\mathrm{a}, \mathrm{b}}$ & $0.18^{\mathrm{b}}$ & $0.07^{\mathrm{a}}$ \\
Protein & $5.14^{\mathrm{c}}$ & $3.9^{\mathrm{a}}$ & $4.03^{\mathrm{b}}$ \\
Crude Fiber & $9.60^{\mathrm{c}}$ & $7.25^{\mathrm{b}}$ & $4.95^{\mathrm{a}}$ \\
Calcium oxalate & $0.56^{\mathrm{a}}$ & $0.76^{\mathrm{b}}$ & $0.75^{\mathrm{b}}$ \\
\hline
\end{tabular}

Different superscripts among mean values in each row indicated a significant difference $(p \leq 0.05)$ - = no color (negative/indicated no starch content)

In the multilevel concentration method, at the first stage, the porang tuber was extracted using $60 \%$ ethanol. The high moisture content of porang tubers is $84.01 \%$ (Table 1) adding polarity to the $60 \%$ ethanol solution used as a solvent in the extraction process, so at this stage, polar impurities such as protein and sugar more easily dissolved ( $X u$ et al., 2014) In the second stage, we use $80 \%$ ethanol. The high moisture content of the tuber was reduced the ethanol concentration to moderate polarity, caused the starch to dissolve. Whereas in the third stage, low polarity (96\% ethanol) caused dissolved fat, crude fiber, and calcium oxalate.

Decreasing of lipids, protein, and crude fiber content in glucomannan extract (Table 3) compared to the porang tubers before extracting, indicated that the components were dissolved and washed out by ethanol solution. While, the ash content in glucomannan extract was higher than in porang tubers, due to the moisture content in porang tubers very high compared to glucomannan extracts. That affects the amount of ash content. Ash content indicates the mineral content of the material (Koswara, 2013). Ash content contained in the obtained glucomannan still meets the requirements of the standard by The Ministry of Agriculture of the People's Republic of China (2002).

The glucomannan content in this study was lower compared to our previous study using ethanol absolute with the same method: multilevel concentration method (Nurlela, Ariesta, Santosa, \& Muhandri, 2019). Due to the higher purity of ethanol absolute compared to technical grade ethanol, which has an impact on the effectiveness of extraction in dissolving impurities.

For the scale-up purposes and mass production of glucomannan flour, the use of technical grade ethanol was certainly more economical. In this study, the glucomannan obtained by the multilevel concentration method of ethanol technical grade, considered as common konjac flour (the glucomannan level is $\geq$ $60 \%$ on dry basis) according to the standard by The Ministry of Agriculture of the People's Republic of China (2002). In Indonesia, the refined porang flour with $60 \%$ glucomannan content is sold at Rp. $250,000 / \mathrm{Kg}$, while porang chips are sold at Rp. $27,000 / \mathrm{Kg}$ (Saputro, Lefiyanti, \& Olim, 2014).

\section{Calcium Oxalate}

Oxalic acid in plants is stored in two forms, watersoluble oxalate and water-insoluble oxalate (Ardhian et al., 2013). Insoluble oxalate compound in porang is calcium oxalate. The benefits of the presence of calcium oxalate are oxalate poison binding, regulating calcium, and as self-defense against herbivores (Chairiyah, Harijati, \& Mastuti, 2013). But, high concentrations of calcium oxalate can cause irritation and itching. Problems encountered in the development of porang flour as food in Indonesia are the high content of calcium oxalate, which causes itching, brownish color, and relatively low glucomannan content around $47-48 \%$ (Sumarwoto, 2014). Those characteristics of porang flour cause a low selling price.

Glucomannan extracted by FC50, FC96, and MC still contain calcium oxalate, but in a low percentage $0.56-0.76 \%$ (Table 2). Maximum calcium oxalate consumption in adults ranges from 0.6 grams to 1.25 grams per day for six consecutive weeks (Jiang et al., 2011). Foods with low oxalate levels don't need to be removed because calcium oxalate in food is not efficiently absorbed by the body, so consumption of foods with low oxalate levels will not have a significant effect on health. The body can also synthesize oxalates from several precursors such as ascorbic acid. 


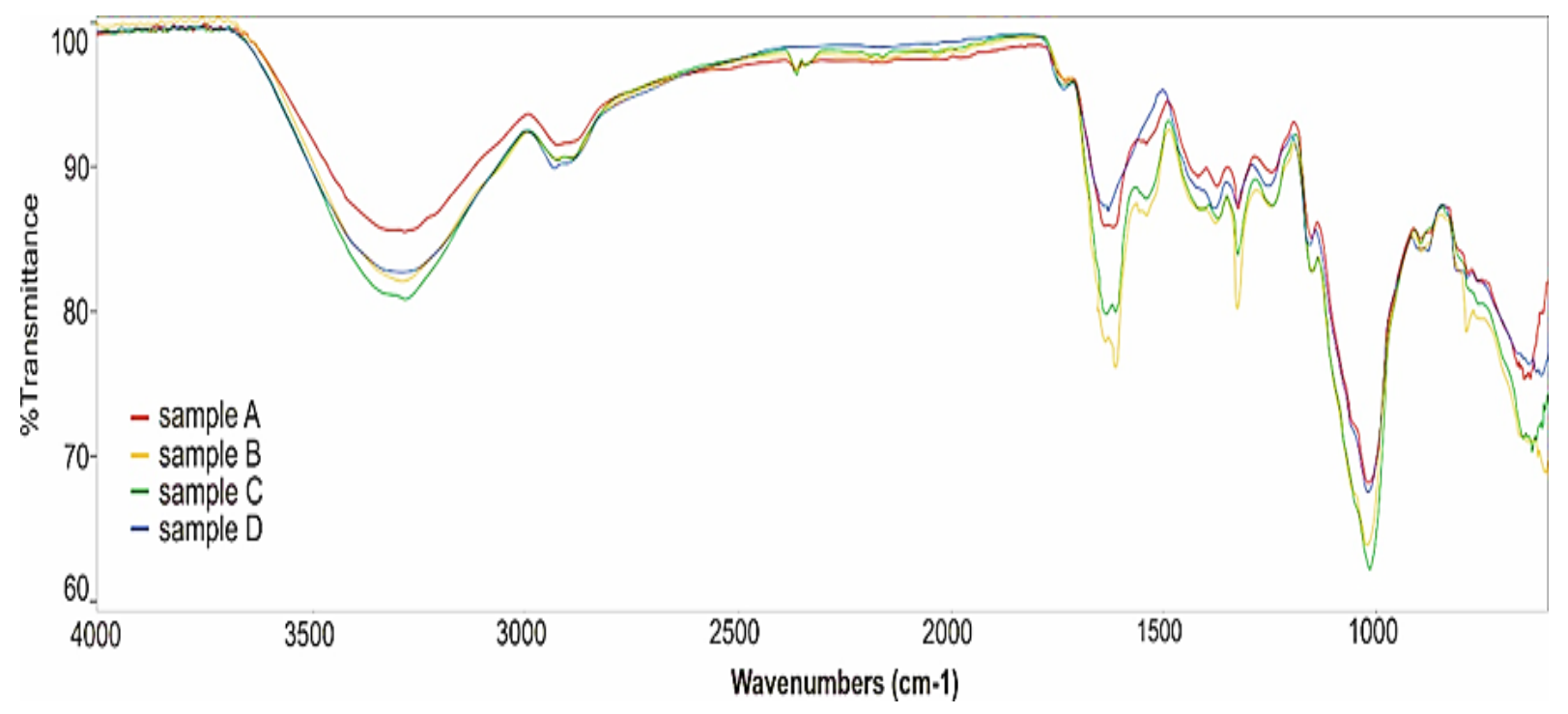

Figure 1. FTIR Spectrum of Glucomannan Granules Extracted by FC50\% (sample A), FC96\% (sample B), MC (sample C), and Commercial Glucomannan (sample D)

Fourier Transform Infra-Red (FTIR) Analysis of Glucomannan

Figure 1 showed the FTIR spectra of the glucomannan in the wavelength range of 4000-400 $\mathrm{cm}^{-1}$. The FTIR spectra of the glucomannan obtained by fixed concentration $50 \%$ ethanol (sample A), fixed concentration $96 \%$ ethanol (sample B), multilevel concentration (sample C) and compared to the commercial glucomannan (sample D) had almost the same absorption band pattern but with different intensities. The broadband was observed at 3000 $3600 \mathrm{~cm}^{-1}$ represented to the $\mathrm{O}-\mathrm{H}$ stretching of the glucose and mannose of glucomannan. Absorption bands in the range of $2850-2925 \mathrm{~cm}^{-1}$ shown stretching asymmetry and symmetry vibration of the alkane group. The strong peak at $1600-1700 \mathrm{~cm}^{-1}$ indicated the presence of the carbonyl group $(C=O)$. Absorption bands at $\pm 1444 \mathrm{~cm}^{-1}$ and $1383 \mathrm{~cm}^{-1}$ showed asymmetric bending vibrations and symmetries of $\mathrm{CH}, \mathrm{CH}_{2}$, and $\mathrm{CH}_{3}$. The $\mathrm{C}-\mathrm{O}$ group on the alcohol bond could be seen in the uptake of the $1027 \mathrm{~cm}^{-1}$ band. The peaks at $875 \mathrm{~cm}-1$ and 805 $\mathrm{cm}-1$ belonged to the characteristic peak of the mannose (Da Silva et al., 2020; Wang, Lee, Yuan, Wang, \& Lu, 2020; Wang, Zhou, Wang, \& Li, 2015).

\section{Scanning Electron Microscope (SEM) Analysis}

Figure 2 showed the morphologies of glucomannan granules extracted by fixed concentration $50 \%$ ethanol (A), fixed concentration 96\% ethanol (B), multilevel concentration (C) with $200 \mathrm{X}$ magnification showed that the granules form of glucomannan were round and oval. The surface of the glucomannan granules was still covered by impurities, but the surface of glucomannan granules extracted by the multilevel concentration of ethanol
(C1) more clear than FC50 and FC96. The native structure of konjac glucomannan was primarily composed of lamella structure units (Manab, Purnomo, Widjanarko, \& Radiati, 2016), as seen in Figure 2.C1.

From the micrographs with $3000 \mathrm{X}$ magnification, the shape of particles from glucomannan obtained by FC96 (B2) and MC (C2) begins to transition from the amorphous phase to the crystalline phase. The transition was shown by the formation of irregular cubes, whereas it was not found in FC50 (A2). There are needle-shape crystals in figures $\mathbf{B} 2$ and $\mathbf{C 2}$, which show the presence of calcium oxalate crystals. The shape of calcium oxalate crystals is like a needle (Koswara, 2013). As seen in Figure 2, needle-shape crystals are more visible in figures B2 (FC96) and C2 (MC) than in figure A2 (FC50). This was consistent with the results of the calcium oxalate data in Table 2 that the calcium oxalate content in glucomannan obtained by FC96 and $M C$ were higher $(0.76 \%$ and $0,75 \%)$ than in glucomannan obtained by FC50 (0,56\%).

\section{X-Ray Diffraction (XRD) Analysis}

XRD analysis was conducted to determine the crystallization of glucomannan. Figure 3 showed that the XRD pattern of glucomannan obtained by FC96 and MC were similar, exhibited very broadband, indicated the amorphous phase begins to transition to the crystalline phase. It was related to the SEM image (Figure 2.B2 and C2). Both diffractograms had high peaks at $2 \theta=20-25^{\circ}$ (Wu et al., 2012). XRD pattern of FC 50 exhibited sharper peak and higher intensity than the others. It can be concluded that the glucomannan extracted by FC50, FC96, and MC contain more amorphous form than the crystalline form. 

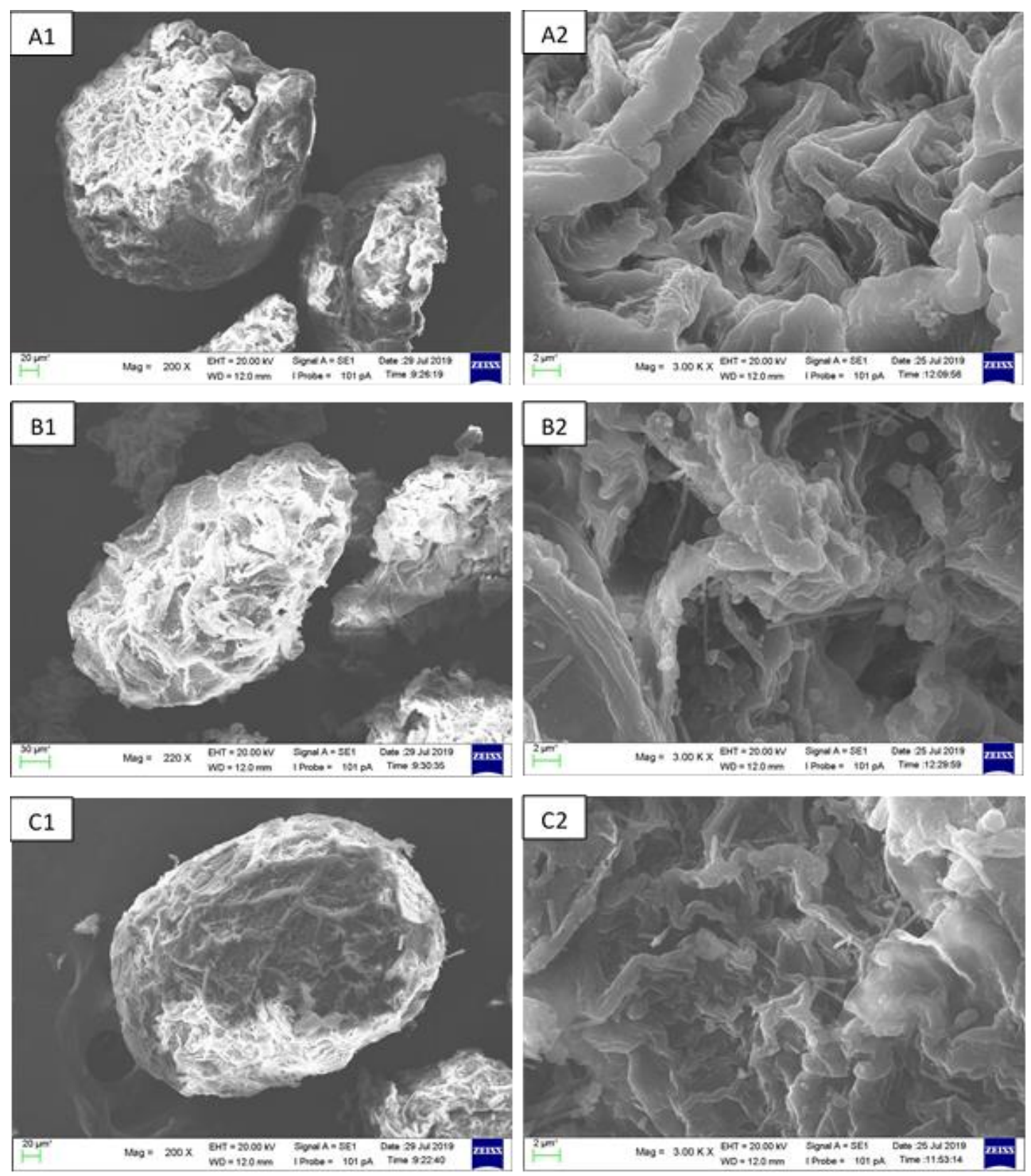

Figure 2. SEM Image of Glucomannan Granules Extracted by FC50 (A), FC96 (B), MC (C) with 200X (1), 3000X (2) Magnification

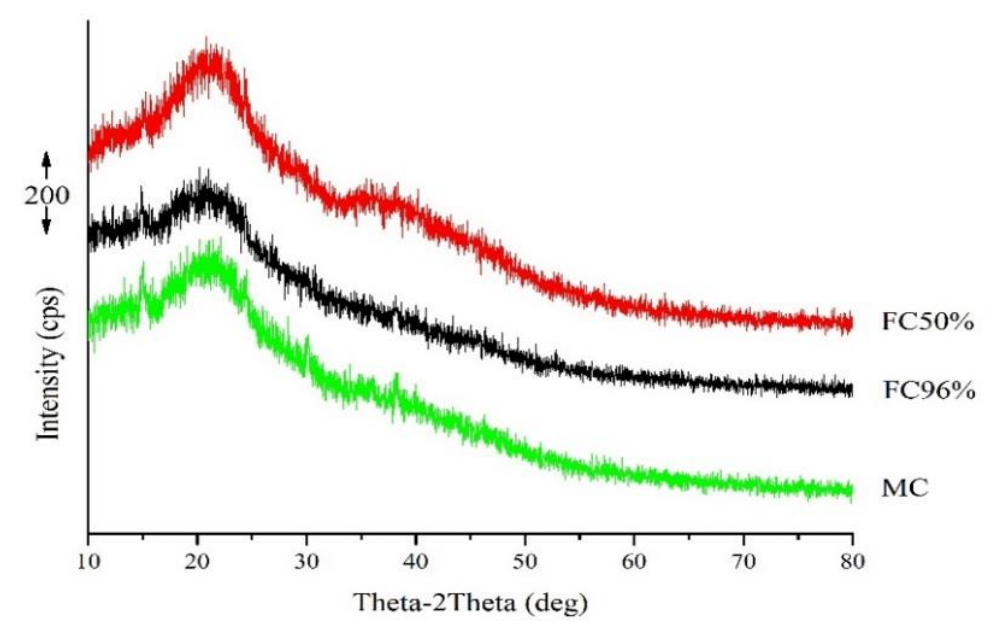

Figure 3. XRD Pattern of Glucomannan Granules Extracted by FC50 (A), FC96 (B), MC (C) 


\section{CONCLUSIONS}

The highest glucomannan content (66.56\%) was obtained by the multilevel concentration method (MC). Moisture, lipid, protein, crude fiber, calcium oxalate level significantly reduce to $13.58 \%, 0.07 \%$, $4.03 \%, 4.95 \%, 0,56 \%$ respectively. FTIR spectra confirmed the presence of functional groups $(\mathrm{O}-\mathrm{H}$, $\mathrm{C}=\mathrm{O}, \mathrm{C}-\mathrm{O}, \mathrm{C}-\mathrm{H})$, that compose the glucomannan compound. SEM image showed that the granules form of glucomannan were round and oval, began to change its phase from amorphous to crystalline, related to XRD data. The results showed that the direct extraction from fresh porang tuber using ethanol technical grade with a multilevel concentration method was an effective method to extract the glucomannan.

\section{ACKNOWLEDGMENT}

This research has been funded by the Directorate of Research and Community Service, DirectorateGeneral for Research and Development, Ministry of Research, Technology and Higher Education of Indonesia.

\section{REFERENCES}

Ardhian, Dhike \& Indriyani, S. (2013). Content of Oxalate in Porang Tubers (Amorphophallus muelleri Blume) Results of Planting with $\mathrm{P}$ and K Fertilizer treatment. Biotropikal, 1, 53-56.

Association of Official Analytical Chemists. (2007). Official Methods of Analysis of AOAC International. Association of Official Analysis Chemists International, Vol. 1, Virginia: Arlington.

Chairiyah, N., Harijati, N., \& Mastuti, R. (2013). Variation of calcium oxalate ( $\mathrm{CaOx}$ ) crystals in porang (Amorphophallus muelleri Blume). American Journal of Plant Sciences, 4, 17651773.

http://dx.doi.org/10.4236/ajps.2013.49217

Chua, M., Chan, K., Hocking, T. J., Williams, P. A., Perry, C. J., \& Baldwin, T. C. (2012). Methodologies for the extraction and analysis of konjac glucomannan from corms of Amorphophallus konjac K. Koch. Carbohydrate Polymers, 87(3), 2202-2210. https://doi.org/10.1016/i.carbpol.2011.10.0 53

Chua, M., Hocking, T. J., Chan, K., \& Baldwin, T. C. (2013). Temporal and spatial regulation of glucomannan deposition and mobilization in corms of Amorphophallus konjac (Araceae). American Journal of Botany, 100(2), 337-345. https://doi.org/10.3732/ajb. 1200547

Da Silva, D. F., Ogawa, C. Y. L., Sato, F., Neto, A. M., Larsen, F. H., \& Matumoto-Pintro, P, T. (2020). Chemical and physical characterization of Konjac glucomannanbased powders by FTIR and 13C MAS NMR.
Powder Technology, 361, 610-616.

Ho, H. V. T., Jovanovski, E., Zurbau, A., Mejia, S. B., Sievenpiper, J. L., Au-Yeung, F., ...Vuksan, V. (2017). A systematic review and meta-analysis of randomized controlled trials of the effect of konjac glucomannan, a viscous soluble fiber, on LDL cholesterol and the new lipid targets non-HDL cholesterol and apolipoprotein B. The American Journal of Clinical Nutrition, 105(5), $\quad 1239$ 1247. https://doi.org/10.3945/ajcn.116.142158

Jiang, J., Knight, J., Easter, L. H., Neiberg, R., Holmes, R. P., \& Assimos, D. G. (2011). Impact of dietary calcium and oxalate, and oxalobacter formigenes colonization on urinary oxalate excretion. The Journal of Urology, 186, 135-139. https://doi.org/10.1016/j.juro.2011.03.006

Koswara, S. (2013). The technology of Tubers Processing, Part 2: Porang Tubers. Tropical Plant curriculum (TPC) Project. USAID and SEAFAST Center, 5(1), 1-44. Bogor Agriculture University.

Li, B., Shah, B. R., Wang, L., Liu, S., Li, Y., Wei, X., ...Li, Z. (2015). Health benefits of konjac glucomannan with special focus on diabetes. Bioactive Carbohydrates and Dietary Fibre, 5(2), 179-187. https://doi.org/10.1016/i.bcdf.2015.03.007

Li, J., Ye, T., Wu, X., Chen, J., Wang, S., Lin, L., \& Li, B. (2014). Preparation and characterization of heterogeneous deacetylated konjac glucomannan. Food Hydrocolloids, 40, 9-15. https://doi.org/10.1016/i.foodhyd.2014.02.0 01

Manab, A., Purnomo, H., Widjanarko, S. B., \& Radiati, L. E. (2016). Molecular Docking Study on the interaction of $\mathrm{k}$-casein with Glucomannan. International Journal of Current Microbiology and Applied Sciences, 5(3), 651 658.

Mekkerdchoo, O., Lei, Y., \& Jianrong, Z. (2020). Biosynthesis and decomposition of konjac glucomannan. In Srzednicki, G., \& Borompichaichartkul, C. (Ed.), Konjac glucomannan: production, processing, and functional applications. Boca Raton: Taylor \& francis Group, CRC Press.

Nguyen, T. A., Do, T. T., Nguyen, T. D., Pham, L. D., \& Nguyen, V. D. (2011). Isolation and characteristics of polysaccharide from Amorphophallus corrugatus in Vietnam. Carbohydrate Polymers, 84(1), 64-68. https://doi.org/10.1016/i.carbpol.2010.10.074

Nurjanah, Z. (2010). Study of Glucomannan Flour Purification Process from lles-iles Bulbs (Amorphophallus oncophyllus) using the $\alpha$ amylase Enzyme. Thesis. Bogor Agricultural University. 
Nurlela, Ariesta, N., Santosa, E., \& Muhandri, T. (2019). Effect of harvest timing and length of storage time on glucomannan content in porang tubers. IOP Conference Series: Earth and Environmental Science, 299, 012012. https://doi.org/10.1088/1755-

1315/299/1/012012

Parry, J. (2010). Konjac glucomannan. In A. Imeson (Ed.), Food Stabilisers, Thickeners, and Gelling Agents (pp. 198-215). West Sussex: Blackwell Publishing Ltd.

Saputro, E. A., Lefiyanti, Olim, E. M. (2014). Purification of glucomannan flour from porang tubers (Amorphophallus muelleri Blume) using the extraction/leaching process with ethanol solution. Simposium Nasional RAPI XIII, 7-13.

Singh, S., Singh, G., \& Arya, S. K. (2018). Mannans: an overview of properties and application in food products. International Journal of Biological Macromolecules, 119, 79-95. https://doi.org/10.1016/j.ijbiomac.2018.07.130

Sumarwoto, S. (2014). Iles-iles (Amorphophallus muelleri Blume): description and other characteristics. Biodiversitas, Journal of Biological Diversity, 6(3), 185-189. https://doi.org/10.13057/biodiv/d060310

Takigami, S. (2000) Konjac mannan. In Phillips, G. O., \& P. A. Williams (Eds.), Handbook of hydrocolloids (pp. 413-424). Cambridge: Woodhead publishing limited.

Tatirat, O., \& Charoenrein, S. (2011). Physicochemical properties of konjac glucomannan extracted from konjac flour by a simple centrifugation process. LWT - Food Science and Technology, 44(10), 2059-2063. https://doi.org/10.1016/i.lwt.2011.07.019

Tester, R., \& Al-Ghazzewi, F. H. (2017). Role of glucomannans in immunology. Journal of Pharmacy and Pharmaceutical Sciences, 20(1), 97-114. https://doi.org/10.18433/J31P52

The Ministry of Agriculture of the People's Republic of China. (2002). The professional standard of the People' Republic of China for konjac flour, Pub. L. No. NY/T 494-2002.

Wang, J., Liu, C., Shuai, Y., Cui, X., \& Nie, L. (2014). Controlled release of anticancer drug using graphene oxide as a drug-binding effector in konjac glucomannan/sodium alginate hydrogels. Colloids and Surfaces B: Biointerfaces, 113, 223-229.
Wang, L., Lee, A., Yuan, Y., Wang, X., \& Lu, T. (2020). Preparation and FTIR, Raman and SEM characterizations of konjac glucomannan- $\mathrm{KCl}$ electrogels. Food Chemistry, 331, 1-8.

Wang, L., Xiao, M., Dai, S., Song, J., Ni, X., Fang, Y., ... Jiang, F. (2014). Interactions between carboxymethyl konjac glucomannan and soy protein isolate in blended films. Carbohydrate Polymers, 101(1), 136-145. https://doi.org/10.1016/i.carbpol.2013.09.028

Wang, S., Zhou, B., Wang, Y., \& Li, B. (2015). Preparation and characterization of konjac glucomannan microcrystals through acid hydrolysis. Food Research International, 67, $111-116$. https://doi.org/10.1016/j.foodres.2014.11.008 Wu, C., Peng, S., Wen, C., Wang, X., Fan, L., Deng, R., \& Pang, J. (2012). Structural characterization and properties of konjac glucomannan/curdlan blend films. Carbohydrate Polymers, 89(2), 497-503. https://doi.org/10.1016/i.carbpol.2012.03.034

Xu, W., Wang, S., Ye, T., Jin, W., Liu, J., Lei, J., ... Wang, C. (2014). A simple and feasible approach to purify konjac glucomannan from konjac flour - Temperature effect. Food Chemistry, 158, 171-176. https://doi.org/10.1016/i.foodchem.2014.02 .093

Yanuriati, A., Marseno, D. W., Rochmadi, \& Harmayani, E. (2017). Characteristics of glucomannan isolated from fresh tuber of Porang (Amorphophallus muelleri Blume). Carbohydrate Polymers, 156, 56-63. https://doi.org/10.1016/j.carbpol.2016.08.0 80

Ye, T., Wang, L., Xu, W., Liv, J., Wang, Y., Zhu, K., ... Wang, C. (2014). An approach for prominent enhancement of the quality of konjac flour: Dimethyl sulfoxide as medium. Carbohydrate Polymers, 99, 173-179. https://doi.org/10.1016/i.carbpol.2013.08.0 38

Yuan, Y., Wang, L., Mu, R-J., Gong, J., Wang, Y., Li, Y., Wu, C. (2018). Effects of konjac glucomannan on the structure, properties, and drug release characteristics of agarose hydrogels. Carbohydrate Polymers, 190, 196203. https://doi.org/10.1016/i.carbpol. 2018.02.049 